\title{
Socially responsible investment strategies for the transition towards sustainable development: the importance of integrating and communicating ESG

\author{
Mauro Sciarelli, Silvia Cosimato and Giovanni Landi \\ Department of Economics, Management, Institutions (DEMI), \\ University of Naples Federico II, Napoli, Italy, and \\ Francesca Iandolo \\ Department of Management, University of Rome, La Sapienza, Rome, Italy
}

\begin{abstract}
Purpose - Recently, socially and responsible investments (SRI) have constantly grown becoming a highly discussed issue. Therefore, the main purpose of this paper is to better understand if environmental social governance (ESG) criteria integration in investment strategies can support the transition of finance toward a more sustainable growth.

Design/methodology/approach - An explorative analysis based on a multiple case study has been conducted and addressed by a content analysis on the Key Investors Information Documents (KIIDs) that the sample companies published for 2020 .

Findings - The achieved results demonstrated that the case companies differently integrated ESG into their SRI; thus, if some of them are quite near to a full integration, the others demonstrated less than a full commitment with ESG. This seems to be mainly due to the different approach that asset management companies (AMCs) and/or managers have adopted for integrating ESG criteria.

Research limitations/implications - Even though the achieved results offered some interesting insights for asset managers, the explorative and qualitative nature of this study and the small sample investigated somewhat limits it.

Practical implications - AMCs, consultants and managers in developing and implementing their SRI strategy could be much more focused on the importance of ESG integration for the transition toward a more responsible and sustainable finance (micro-level) as well as a more sustainable development (macro-level).

Originality/value - The paper provides new insights into the essence of SRI strategies and their potential to contribute to sustainable development. Thus, it tries to shed new lights on the role that ESG can have to stimulate and support investment decisions and, in so doing, contributing to make finance grow more sustainable.
\end{abstract}

Keywords Socially responsible investments (SRI), Sustainable development, Environmental, Social and governance (ESG), Key investors information documents (KIID)

Paper type Case study

\section{Introduction}

Socially responsible investments (SRI) - also known as ethical or sustainable investments are gaining momentum among scholars and practitioners (Revelli, 2016; Matharu, 2019;

(C) Mauro Sciarelli, Silvia Cosimato, Giovanni Landi and Francesca Iandolo. Published by Emerald Publishing Limited. This article is published under the Creative Commons Attribution (CC BY 4.0) licence. Anyone may reproduce, distribute, translate and create derivative works of this article (for both commercial and non-commercial purposes), subject to full attribution to the original publication and authors. The full terms of this licence may be seen at http://creativecommons.org/licences/by/4.0/ legalcode

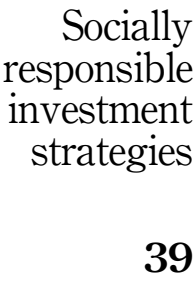

Received 6 August 2020 Revised 14 October 2020 1 November 2020 Accepted 2 November 2020 
TQM

33,7

Arefeen and Shimada, 2020). The extant literature defines them not only as "a result of increasing social awareness by institutions, but primarily as a result of the increasing public (beneficiary) interest in social responsibility" (Cumming and Johan, 2007, p. 397). SRI can be also defined as an investment process that integrates ethical values, environmental protection, improved social conditions and good governance into traditional investment decision-making (Revelli, 2017; Matallín-Sáez et al., 2019; Renneboog et al., 2008). This integration comes through particularly the growing importance that investors place in environmental, social and governance (ESG) criteria, thus bringing out the straightforward link existing between SRI diffusion, a more sustainable economy and, as a consequence, sustainable development (Escrig-Olmedo et al., 2013; P.R.I., 2017; Widyawati, 2019; Gutsche and Zwergel, 2020).

In recent times, scholars, practitioners and policymakers have engaged into a lively debate about the need for an urgent global transition toward sustainable development, to create new opportunities for boosting the "co-evolution of the economic, social, environmental and institutional (governance) systems" (Giljum, 2005, p. 33). It follows that the transition toward sustainable development entails, on the one hand, a rapid reorientation and restructuring of national and international institutions toward more effective governance and with a stronger emphasis on planetary concerns in economic governance, therefore also in investments and finance (Steffen et al., 2015, 2018; Lo and Kwan, 2017). On the other hand, it emphasizes how much the role of finance has changed over time, moving from the exclusive focus on profit maximization and shareholders' wealth to a growing attentiveness about environmental issues like the green and low-carbon economy and the climate change adaptation and mitigation, becoming fundamental in the cited transition toward sustainable development (Ryszawska, 2016).

Despite the increasing spread of SRI, boosted by the growing investors' demand for sustainable products as well as for clear and open information about their functioning (e.g. risks, return, associated costs, etc.) (Oehler et al., 2018), the need for asset management companies (AMCs) to develop more effective strategies, able to balance trust building, accountability as well as ESG informative content and communication is still partially unmet.

Aiming to meet these informative content and communication, in 2012 the European Parliament introduced the Key Investor Information Documents (KIIDs), designed to support potential investors in comparing and choosing funds. AMCs started to voluntarily incorporate additional information on the ESG criteria into their financial reports (Jebe, 2019) to answer the growing investors' need for information about the social and environmental externalities of their asset management practices as well as to make nonfinancial communication clearer and more transparent.

Recent research has underlined that investing in socially responsible funds can benefit from the communication of AMCs' ESG efforts (Renneboog et al., 2008; Ho, 2013; Joliet and Titova, 2018). This has brought several AMCs to be much more focused on the screening of the main ESG criteria - transparency, ethics, impact, environment, society and governance and of the related asset allocation strategies to which they can be added (Przychodzen $e$ al., 2016). The integration of ESG criteria into SRI strategies somewhat justifies investment decisions and, in particular, the decisions of institutional investors, which play an essential role in the transition toward a more responsible and sustainable finance (micro-level) as well as toward a more sustainable development (macro-level) (Crifo et al., 2019). However, literature still calls for better understanding if and how the incorporation of ESG criteria into SRI strategies, the subsequent quality of information and communication may affect investor decision-making. In this sense, the role that KIIDs play on investors' decision-making process still deserves further attention. Thus, this paper aims at contributing to bridging this gap. To this end, an explorative analysis, based on a multiple case study approach has been conducted for addressing the two research questions that inspired this work: 
RQ1. To what extent are ESG criteria integrated into SRI strategies?

RQ2. Do KIIDs contain some possible ESG criteria that can inspire AMC to further develop their SRI strategies?

The remainder of the paper is organized as follows. Section 2 presents the theoretical background of the study, briefly reviewing the existing research on SRI and ESG integration, while Section 3 describes the implemented methods. The achieved results are presented and discussed in Section 4 and 5. Finally, section 6 provides implications and concluding remarks.

\section{Theoretical background}

\subsection{Sustainable development and SRI}

Over the last decade, several direct and indirect links have joined financial development with sustainable development (Scholtens, 2006). In particular, the number of financial and environmental scandals occurred starting from the late '90s on (e.g. Exxon Valdez, Bhopal, Nike, Parmalat, etc.), the negative perception of financial actors during the 2008-2009 crisis and the subsequent pressure of media led AMCs and brokers to increasingly address capitals toward socially responsible funds. This led analysts and fund managers to integrate ESG information into investment strategies to restore social legitimacy and "to expand the scope of the opportunities and risks included in traditional financial analysis" (Revelli, 2017, p. 713).

The resulting growth [1] of SRI directed scholars and practitioners' interest on their potential contribution to the grand challenge of sustainable development as well as to encouraging companies to voluntarily eliminate negative externalities (e.g. pollutant emission, employees' health issues, the safety of work environment, etc.) (Conti, 2017; Chatzitheodorou et al., 2019; Crifo et al., 2019). This implies investors' disposition "to align their investment decisions with their personal values but also incentivizes firms to voluntarily reduce their unintended negative impact on society" (Vanwalleghem, 2017, p. 12).

SRI is a generic term used for those investments that combine "the traditional financial perspective with a perspective that is influenced by and oriented towards social and environmental issues" (Michelson et al., 2004, p. 1). At strategic level, this combination implies the integration of ethical values, environmental protection, improved social conditions and good governance into traditional investment decision-making (Revelli, 2017; Matallín-Sáez et al., 2019; Renneboog et al., 2008). At operative level, the aforementioned combination represents one of the major drivers of the transition toward and the contribution to sustainable finance and, consequently, to sustainable development (Eurosif, 2016; World Economic Forum, 2011). In fact, a well-developed and ethically oriented financial system can contribute to the achievement of the global goal of sustainable development and to build a more sustainable society to live in (Bouma et al., 2017; WBCSD, 1987).

SRI are also able to combine a "fundamental analysis and engagement with an evaluation of the ESG factors to better capture long term returns for investors, and to benefit society by influencing the behavior of companies" (Eurosif, 2016, p. 9). Drawing on this definition, research on the topic (ENG, 2016; Formánková et al., 2019) recognizes different SRI screening strategies, which have evolved consistently along with investors' awareness about social and environmental issues. The screening strategies can be framed as follows: (1) negative screening, which seeks to avoid investments in so-called "sin" sector, (2) positive screening, which seeks to include leaders in corporate social responsibility in the investment opportunity set, (3) investor engagement, which seeks to create a mutual dialog pointing to change ESG companies' behavior, building strong and long-lasting personal relationships

\section{Socially responsible investment strategies}


TQM

33,7

and trust and (4) best-in-class, which select leading companies on environmental and/or CSR issues.

Recently, performance-based SRIs have been related to a specific asset management strategy, the ESG integration (Revelli, 2017). At operative level, the integration of ESG criteria into investment strategies has been recognized as one of the main enablers for SRI market (Widyawati, 2019). Therefore, a growing number of private investors and AMCs have spent resources on ESG integration as well as into their communication (Busch et al., 2016). It follows that the integration of ESG criteria (e.g. climate change, income inequality, etc.) into business strategies and practices is what contribute to the definition of sustainability in finance (Kotsantonis et al., 2016) and which makes it appealing to investors and companies. Thus, the following section is dedicated to ESG integration and communication and the related additional informative documents.

\subsection{ESG integration in SRI for contributing to sustainable development}

The term "integration" was used for the first time by Novoethic [2] for defining a new form of SRI emerging from investors who integrated nonfinancial criteria into a conventional financial analysis process, which supported their institutionalization in markets (Revelli, 2016). However, ESG integration has been also defined as less restrictive SRI that "involves consideration by conventional management (also called mainstream) of some environmental, social and governance (ESG) key criteria or to make ESG analysis available to all management teams, or to encourage joint work between financial and extra-financial analysts" (Novoethic, 2010, p. 10). It follows that as an asset management strategy ESG integration implies a wider perspective on investment analysis, merging the screening of financial and nonfinancial dimensions, opportunities and issues (Van Duuren et al., 2016; Chen et al., 2018). This led investors to pay attention to the link between ESG adopting entities (e.g. companies, states, etc.) and their financial performance when considering ethics as reliable fund-raising leverage (Jebe, 2019).

On this ground, in 2018 SASB [3] issued the material ESG standards at the industry level, given their financial relevance for investors due to their influence on financial performance. According to the UNPRI [4] (2015), the nonfinancial information - following the ESG criteria concerns environment when related to pollution, gas emissions, climate change, waste management, biodiversity loss, stratospheric ozone depletion, renewable energy and natural systems; society when related to human well-being, good working conditions, human rights and similar and, finally, governance when focused on board size, structure and independence, gender diversity, skills development, internal control, easy access to information, ethical codes, shareholder relations and engagement.

As a consequence, AMCs demonstrated growing attention to ESG information accuracy, transparency and reliability publicly ensured through specific communication tools, intended to support those investors who are willing to pay a moral fee for the inclusion of ESG criteria into their portfolio decisions (Belghitar et al., 2014; del Mar Miralles-Quirós et al., 2017).

This is in line with the general assumption according to which consumers evaluate and even tend to be willing to pay for special ethical and/or sustainable products' features (Nilson et al., 2016). It follows that for AMC communicating their sustainable finance policy is essential for improving customers' perception of the quality and effectiveness of their products, boosting, at the same time, their propensity to choose them (Palma-Ruiz et al., 2020). The extant research (Biong and Silkoset, 2017; Ashrafi et al., 2018; Parrida and Wnag, 2018) has also underlined that the exploitation of sustainable and CSR communication can support AMC in gaining stakeholders' trust. However, when investors consider "not only economic factors but also environmental and/or social factors when making investment decisions, their analysis will be much more accurate. This is the standpoint of the so-called triple bottom line (TBL) 
approach, first introduced by Elkington (1997)" (Cubas-Díaz and Martinez Sedano, 2018, p. 17) and based on the merging of people, planet and profit interests. This means that to meet investors' expectations, ESG integration should rely on specific communication tools and shared informative contents, able to generate positive externalities, risk-adjustment factors and value-enhancing drivers (Derwall et al., 2011; Landi and Sciarelli, 2019). To this purpose, in 2012, with the European UCITS IV directive, the European Parliament introduced the KIID (Key Investor Information Documents) for supporting potential investors in comparing and choosing among different funds. This is a public, standard, plainly worded and consumer-friendly document, which provides essential information for supporting the investment decision-making. KIID also discloses a product's riskiness using a summary risk indicator, its potential performance, defining a performance and costs scenario, using specific cost indicators (Ceravolo et al., 2019). The analysis of the KIIDs supports investors to identify and assess the effective integration of the ESG criteria in the different asset management activities. Hence, to understand the level of integration of the ESG criteria within investments funds, in what follows the analysis of the KIID is proposed.

\section{Materials and methods}

\subsection{Research approach and case study selection}

This paper is exploratory in nature and aims at contributing to the call for further research on the implications of SRI for the transition toward sustainable development. Therefore, a qualitative method, based on the analysis of multiple case study (Stake, 2013) was performed for gaining insights about the topic under investigation. The implemented method is particularly fitting for understanding emerging phenomena "when how and why questions are being posed when the investigator has little control over events, and when the focus is on a contemporary phenomenon within some real-life context, especially when the boundaries between phenomenon and context are not clearly evident" (Yin, 2003, p. 50). To this end, a content analysis was conducted (Krippendorff, 2004; Kohlbacher, 2006) on the KIIIs that the case companies (AMCs active in SRI) published for 2020.

The overall quality of the analysis was ensured through (1) the construct validity, achieved establishing suitable operational measures for the analyzed concepts (e.g. investor engagement with ESG) and (2) the internal validity achieved basing the content analysis on well-established items (or themes) and indicators (Mason and Bramble, 1989). Items and indicators have been developed drawing on previous research (Lokuwaduge and Heenetigala, 2017; Escrig-Olmedo et al., 2019; Capelle-Blancard and Petit, 2019), while the internal validity of the analysis was boosted triangulating several different sources of data apart from the KIIDs, such as corporate posts on the website and social media, reports, brochures, online news, etc. or asking some key informants where possible.

\subsection{The case companies' selection}

As stated, the analysis has been focused on a multiple case study approach; thus, the research questions at the core of the study and the implementation of a nonprobabilistic technique (Newman, 2003) drove the case companies' selection. To this end, a convenience sampling strategy was implemented, using the following sampling criteria: (1) longevity, (2) portfolio characteristics, (3) funds characteristics, (4) SRI strategy, (5) rating and (6) financial markets.

The selected case companies are pioneers in ESG investing and ESG communication. Moreover, their mission is fully centered on a proactive and holistic approach to social responsibility that led them to go beyond the merely responsible approach to investments. Over time, the case companies actively stimulated the financial community and, therefore, investors as well as all the other stakeholders to responsibility act and perform, promoting 
TQM

33,7

\section{4}

their engagement. In this direction, these companies developed and implemented some specific strategies to improve investor trust and commitment to the investment process and, of course, to ESG actions. Follows a brief summarization of case companies' main characteristics (Table 1).

The strategies that the case companies mostly implemented for promoting their products were: (1) Best-In-class, (2) Best-In-class; investor engagement, (3) negative screening, (4) negative screening; Investor engagement and (5) positive screening.

Finally, the asset composition of ESG products is made up of $53 \%$ share securities, $24 \%$ bond securities, $21 \%$ multi-asset securities and $2 \%$ currency securities (Figure 1). For the analysis 70 products have been selected and analyzed.

\subsection{Data collection and content analysis}

To better understand the way AMCs approached ESG into their SRI strategies, a content analysis was performed. The analysis was conducted on the English version of 120 KIIDs related to the selected 70 ESG products, which have been organized in two different classes: the first defined according to the ESG strategies implemented in asset management and the second defined applying a thematic filter, based on some ESG key issues identified in previous research.

The implemented method supported the interpretation of the quantitative counts of the coded texts descriptively. For this purpose, some content units (or "observation" in inferential statistics) were defined; thus, each sentence reported into the analyzed documents was considered as a content unit, which "set the limits on the information to be considered in the

Table 1.

Case companies' main characteristics

\begin{tabular}{lccccc}
\hline & \multicolumn{5}{c}{ Case companies } \\
& $A$ & $B$ & $C$ & $D$ & $E$ \\
\hline Age of foundation & 1996 & 2010 & 2000 & 1978 & 1985 \\
Location & Luxembourg & Paris & Milan & Atlanta & Wien \\
SRI asset class & 29 & 22 & 6 & 5 & 8 \\
Asset under management & 121 Billion $€$ & 276 Billion $€$ & 3.5 Billion $€$ & 67.1 Billion $\$$ & 6 Billion CHF \\
(SRI) & & & & & \\
Source(s): authors' elaboration & & & & \\
\end{tabular}

\section{ASSET COMPOSITION OF ESG PRODUCTS}

Figure 1.

Asset composition of case companies' ESG products

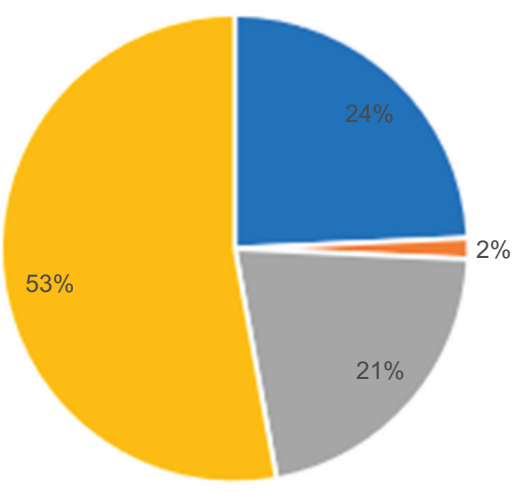

Source(s): Authors' elaboration
"BOND SECURITIES

\#CURRENCY SECURITIES

= MULTI-ASSET SECURITIES

"SHARE SECURITIES 
description" (Krippendorff, 2004, p. 101), while the word was set as a unit of analysis. Three researchers worked independently and checked the selected texts to correct eventual coding errors. As stated, data were triangulated (Houghton et al., 2013) to test the observations and the interpretations coming from the content analysis. Some specific rules were defined and organized into a dictionary to reduce the subjective influence of the researchers on data gathering and analysis. The dictionary consisted of a list of words referred to the coding categories defined drawing on previous research on ESG issues (Freide et al., 2015; Syed, 2017): (1) Society and governance, (2) climate change, (3) healthcare, (4) global compact and (5) sustainable development.

The exhaustiveness of the word list, consisting of160 keywords (in which singulars and plurals have been previously grouped), without articles, articles, auxiliaries and prepositions, was ensured using an English dictionary of synonyms and antonyms (Table 2). Keywords have been selected analyzing, as stated, the literature on the topic (Tsai et al., 2009; Dillenburg et al., 2003; Freide et al., 2015; Syed, 2017)

The units of analysis (words) were organized and classified according to the five coding categories defined before. Words detection was conducted using NVivo7 software, and the selection criterion was the following, keywords which appeared at least one time in the analyzed texts, due to limited length of analyzed documents (about two pages). Results were organized in a word-count matrix to make items easily comparable and to define specific patterns or tendencies (see Appendix).

\section{Results}

The results achieved performing the content analysis on the KIIDs of the selected case companies have been synthesized and presented in the following tables and figures. Starting from the original 160 keywords (indicators), just 96 are reported into the word-count matrix (see Appendix) because they adhere to the aforementioned selection criteria (see Tables 3-7).

Focusing on the case company (case company $A$ ), the analysis demonstrated that the most recurrent keywords belonged to the categories society and governance (1.134) and sustainable development (1.841), while the category with fewer occurrences was global compact (240). It is worth noting that the most recurrent three keywords were invest* (552), belonging to the ESG

Word list

Access, age, accounting, anticorruption, association*, award*, bank*, biodegradable*, biodiversity*, board*, business, care*, carbon, change*, children*, climate, clinic*, collect*, commit*, communication, communit*, compact, compensation*, competit*, complian*, condition*, consumption, corporat*, CSR, culture, customer*, chronic, democracy, disease*, disclosure, diversit*, doctor*, econom*, educat*, effective*, efficien*, elder, emission*, employ*, energy*, engagement, environment*, entrepreneur*, equit*, ESG, ethics, expectation*, famil*, finance*, firm*, freedom, fuel*, fund*, future, gas, gain*, gender*, generation, global, govern*, green*, GRI, group*, goal*, happ*, health*, healthcare, hospital*, hunger*, incentive*, indicator*, inequality, information, institution*, integration, invest*, involv*, knowledge, law*, learn*, lobby*, long-term, manag*, market*, material*, medical, medicine, minority, monitoring, natur*, need*, non-discriminat*, objective*, occupation, oil*, opportun*, optimization, orientation, pension*, people, performance*, physician*, polic*, politic*, pollution, poor*, portfolio, poverty, positive, principle*, public, pressure, price, priorit*, problem*, product*, progress, quality, regulation*, religion*, renew*, report*, responsib*, result*, retirement, rich*, right*, risk*, safety, SDG, security, service*, skill*, social, society, source*, SRI, stakeholder*, standard*', stock*, strateg*, support, sustainab*, surgery, target, train*, transport*, use, values, wast*, water, welfare, wellbeing*, wellness, wind, work

Source(s): authors' elaboration

Table 2.

The dictionary containing the list of selected keywords 


\section{TQM 33,7}

\begin{tabular}{|c|c|c|}
\hline Categories & $\begin{array}{l}\text { Occurrences' per } \\
\text { category }\end{array}$ & $\begin{array}{l}\text { Case company A } \\
\text { Keywords }\end{array}$ \\
\hline $\begin{array}{l}\text { Society and } \\
\text { governance }\end{array}$ & 1.134 & $\begin{array}{l}\text { Bank* (40), disclosure (18), equit* (70), fund* (414), govern* (40), } \\
\text { integration ( } 42 \text { ), price ( } 48) \text {, product* (48), quality ( } 30) \text {, regulation* } \\
\text { (24), responsib* (24), result* (336) }\end{array}$ \\
\hline Climate change & 344 & $\begin{array}{l}\text { Carbon (60), collect* (24), emission* (100), energy* (64), global } \\
(24) \text {, natur* (24), source* (48) }\end{array}$ \\
\hline Healthcare & 408 & Condition* (96), information (264), use (48) \\
\hline Global compact & 240 & $\begin{array}{l}\text { Access (24), employ* (24), gender* (24), polic* (96), poverty (24), } \\
\text { work (48) }\end{array}$ \\
\hline $\begin{array}{l}\text { Sustainable } \\
\text { development }\end{array}$ & 1.841 & $\begin{array}{l}\text { compliance (24), communication (34) environment (44), finance* } \\
(160) \text {, firm* (40), future (22), gain* (48), goal* (72), indicator* ( } 74) \text {, } \\
\text { invest* (552), market* (93), objective* (116), opportun* (84), } \\
\text { performance* (182), public (48), risk* (142), strategy (46), value* } \\
(60)\end{array}$ \\
\hline Total occurrences & 3.967767 & \\
\hline \multicolumn{3}{|c|}{ Source(s): authors' elaboration } \\
\hline
\end{tabular}

Table 3.

Keywords occurrences into case company A KIIIDs

Source(s): authors' elaboration

\begin{tabular}{lcl}
\hline Categories & $\begin{array}{c}\text { Occurrences' per } \\
\text { category }\end{array}$ & $\begin{array}{l}\text { Case company B } \\
\text { Keywords }\end{array}$ \\
\hline $\begin{array}{l}\text { Society and } \\
\text { governance }\end{array}$ & 720 & $\begin{array}{l}\text { Bank* (90), equit* (60), fund* (170), govern* (58), institution* } \\
\text { (52), integration (24), law* (34), product* (48), quality (34), } \\
\text { regulation* (20), result* (130) } \\
\text { Association* (72), collect* (27), global (40), natur* (24), source* } \\
\text { (48) }\end{array}$ \\
$\begin{array}{l}\text { Climate change } \\
\text { Healthcare }\end{array}$ & 211 & $\begin{array}{l}\text { (42) } \\
\text { Access (96), employ* (10), polic* (100), work (50) }\end{array}$ \\
$\begin{array}{l}\text { Global compact } \\
\text { Sustainable } \\
\text { development }\end{array}$ & 266 & $\begin{array}{l}\text { Environment (112), finance* (192), firm* (24), freedom (20), } \\
\text { future (96), gain* (48), goal* (72), indicator* (36), invest* (672), } \\
\text { market* (100), objectiv** (64), opportun* (68), performance* } \\
\text { (192), public (24), risk* (301), strategy (96) }\end{array}$ \\
$\begin{array}{l}\text { Total occurrences } \\
\text { Source(s): authors' elaboration }\end{array}$ & 2.017 &
\end{tabular}

category, fund* (414) and result* (336), belonging to sustainable development. Finally, the keyword with fewer occurrences was disclosure (18), belonging to society and governance.

The analysis of the second case company (case company B) demonstrated that the most recurrent keywords belonged to the categories society and governance (720) and sustainable development (2.017), while the category with fewer occurrences was climate change (211). The most recurrent three keywords were investment* (672) and risk* (301), belonging to society and governance, and age (417), belonging to healthcare. Finally, the keyword with fewer occurrences was employ* (10), belonging to the category global compact.

The analysis of case company C SGR documents showed that the keywords with the highest number of occurrences belonged to the categories society and governance (1.000) and sustainable development (2.195), while the category with fewer occurrences was global compact (295). The most recurrent three keywords were risk* (401) and invest* (322), belonging to the 


\begin{tabular}{|c|c|c|}
\hline Categories & $\begin{array}{l}\text { Occurrences' per } \\
\text { category }\end{array}$ & $\begin{array}{l}\text { Case company C } \\
\text { Keywords }\end{array}$ \\
\hline $\begin{array}{l}\text { Society and } \\
\text { governance }\end{array}$ & 1.000 & $\begin{array}{l}\text { Bank* (24), ethics (153), fund* (370), govern* }(68) \text {, institution* } \\
\text { (95), law* (54), price }(60) \text {, product* }(38) \text {, regulation* }(40) \text {, result* } \\
\text { (98) }\end{array}$ \\
\hline Climate change & 332 & $\begin{array}{l}\text { Association* (62), climate (24), emission (26), energy (60), global } \\
\text { (48), natur* (24), source* (88) }\end{array}$ \\
\hline Healthcare & 491 & Age (280), Condition* ${ }^{*}(113)$, information (98) \\
\hline Global compact & 295 & $\begin{array}{l}\text { Compact (32), employ* (112), gender, (45), group (20), problem } \\
\text { (32), polic* (64), work (30) }\end{array}$ \\
\hline $\begin{array}{l}\text { Sustainable } \\
\text { development }\end{array}$ & 2.195 & $\begin{array}{l}\text { Environment (112), finance* (302), firm* (24), indicator }(65) \text {, } \\
\text { invest* (322), long-term (20), future (196), gain* (68), goal* (112), } \\
\text { market* }(80) \text {, performance* }(200) \text {, principle* }(20) \text {, objective* }(64) \text {, } \\
\text { opportun* (68), strategy (36), risk* (401), value (104) }\end{array}$ \\
\hline
\end{tabular}

Source(s): authors' elaboration

\section{Socially responsible investment strategies}

Table 5.

Keywords occurrences into case company

C KIIDs

\begin{tabular}{lcl}
\hline Categories & $\begin{array}{c}\text { Occurrences' per } \\
\text { category }\end{array}$ & $\begin{array}{l}\text { Case company D } \\
\text { Keywords }\end{array}$ \\
\hline $\begin{array}{l}\text { Society and } \\
\text { governance }\end{array}$ & 1.081 & $\begin{array}{l}\text { ESG (31), fund* (864), manag* (64), price (29), product* (18), } \\
\text { quality (24), responsib* (20), service (31)* }\end{array}$ \\
$\begin{array}{l}\text { Climate change } \\
\text { Gealthcare }\end{array}$ & 362 & $\begin{array}{l}\text { Gobal (240), material* (20), natur* (60), source* (24), water (18) } \\
\text { Information (84), use (24) }\end{array}$ \\
$\begin{array}{l}\text { Sustainable } \\
\text { development }\end{array}$ & 108 & $\begin{array}{l}\text { Gender* (23), knowledge (63), skill* (122), value (21) } \\
\text { Finance* (67), future (63), goal* (78), indicator* (181), invest* } \\
(840), \text { long-term (40), market* (60), performance* (216), } \\
\text { objective* (65), politic* (22), principle* (64), public (80), risk* } \\
(245), \text { strateg* (24), society (24), value* (24) }\end{array}$ \\
Total occurrences & 2.093 &
\end{tabular}

Source(s): authors' elaboration

Table 6.

Keywords occurrences into case company

D KIIDs

\begin{tabular}{|c|c|c|}
\hline Categories & $\begin{array}{l}\text { Occurrences' per } \\
\text { category }\end{array}$ & $\begin{array}{l}\text { Case company E } \\
\text { Keywords }\end{array}$ \\
\hline $\begin{array}{l}\text { Society and } \\
\text { governance }\end{array}$ & 1.115 & $\begin{array}{l}\text { Bank* (88), ethics }(153) \text {, fund* }(370) \text {, govern* }(54) \text {, institution* } \\
\text { (95), law* (44), price ( } 78) \text {, product* (38), regulation* }(60) \text {, } \\
\text { responsibility (24), result* (111) }\end{array}$ \\
\hline Climate change & 142 & Global (48), natur* (50), source* (44) \\
\hline Healthcare & 130 & Age (6), information (124) \\
\hline Global compact & 385 & $\begin{array}{l}\text { Compact (32), employ* (130), gender, (45), group (20), pension } \\
\text { (24), problem (32), polic* (72), work (30) }\end{array}$ \\
\hline $\begin{array}{l}\text { Sustainable } \\
\text { development }\end{array}$ & 1.995 & $\begin{array}{l}\text { Environment (112), finance* (88), firm* (24), indicator (65), } \\
\text { invest* (322), future (201), gain* (68), goal* (102), long-term (21), } \\
\text { market* (69), performance* (200), principle* (24), objective* (94), } \\
\text { opportun*, (68), risk* (341), society (29), strategy (43), value (124) }\end{array}$ \\
\hline
\end{tabular}

Source(s): authors' elaboration

Table 7 .

Keywords occurrences into case company E KIIIs 
TQM

33,7

48

sustainable development and fund* (370), belonging to society and governance, while the keyword with fewer occurrences was principle* (20), belonging to sustainable development.

The analysis of the fourth case company (case company D) pointed out that the most recurrent keywords belonged to society and governance (1.081) and sustainable development (2.093), while the category with fewer occurrences was healthcare (108). The most recurrent three keywords were fund* (864) invest* (840) and risk* (245) all belonging to the sustainable development category, while the keyword with fewer occurrences was principle* (20), belonging to sustainable development.

Finally, the analysis of the last case company (case company E) highlighted that the most recurrent keywords belonged to the categories society and governance (1.115) and sustainable development (1.995), while the category with fewer occurrences was healthcare (130). The most recurrent three keywords were fund* (370), belonging to society and governance, risk* (341) and invest* (322), belonging to sustainable development, while the keyword with fewer occurrences was group* (20), belonging to global compact.

The analysis also demonstrated that the case company with the highest number of keywords occurrences was, case company $\mathrm{C}$ (4.313), the companies the lower number was case company E (3.767), while for the case company B and case company D the total number of occurrences was very similar (case company B 3.871 and case company D 3.875) (Figure 2).

The analysis led also to highlight the most recurrent categories in the analyzed documents; thus, the two that mostly recurred were society and governance and sustainable development, while the category with fewer occurrences was climate change (Figure 3).

Finally, the most recurrent three keywords were fund $^{*}$, belonging to society and governance (864 occurrences) retrieved into case company D KIIDs, invest* belonging to sustainable development (672 occurrences) retrieved into case company B KIIDs and age* belonging to healthcare (417 occurrences) retrieved into the same KIIDs.

\section{Discussions}

The content analysis was implemented to examine a sample of KIIIDs that the case companies published for 2020 to understand if and to which extent they were performing and promoting the transition toward sustainable development. In this sense, the integration of ESG criteria into their SRI strategies represented an important action to communicate this transition both

Figure 2.

Total number of occurrences per each case company

\section{Occurences per each case company}

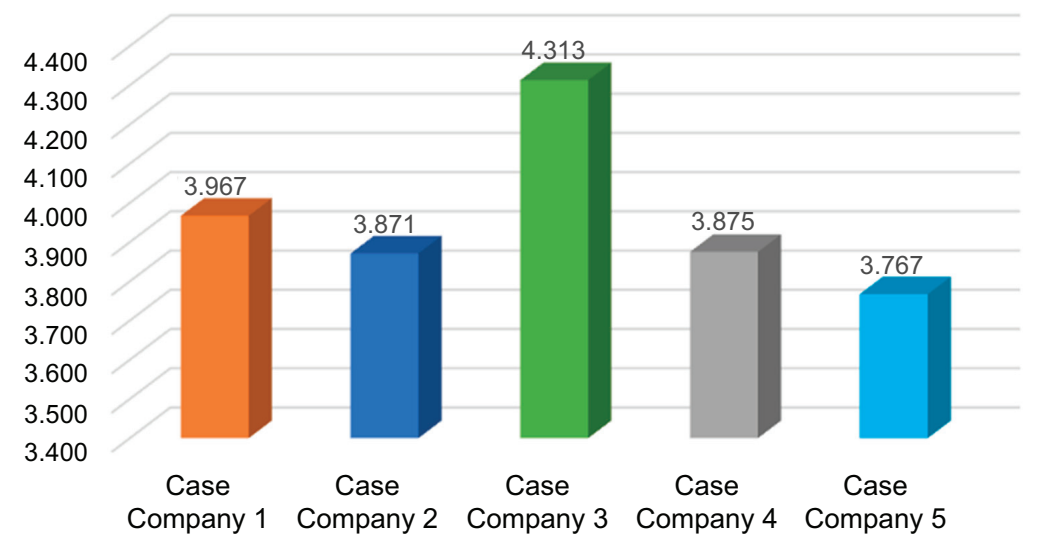

Source(s): Authors' elaboration 
Most and less occurence categories (average)

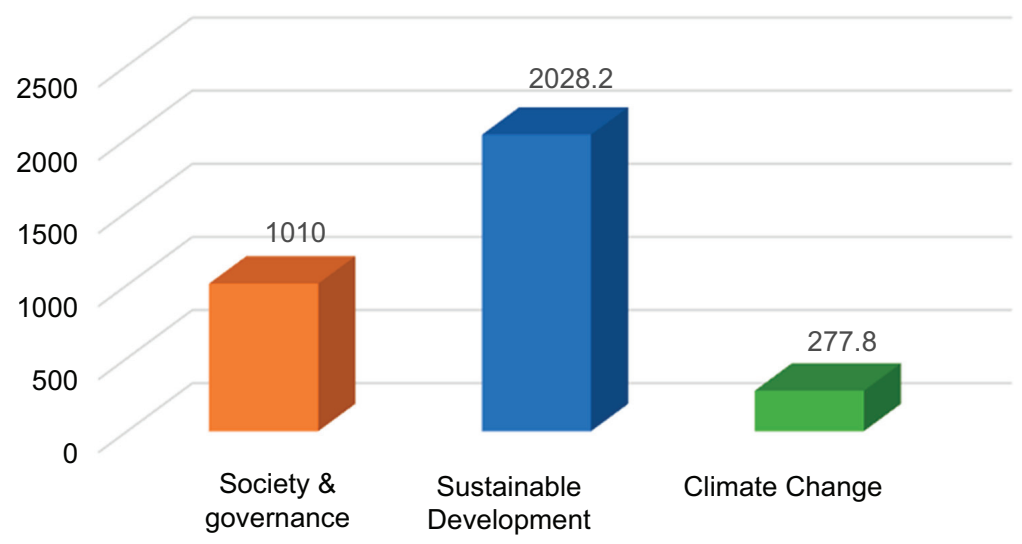

Source(s): Authors' elaboration

\section{Socially responsible investment strategies}

Figure 3.

Most and less recurrent categories (average)

to investors and to a more general audience interested in socially responsible investments. In this sense, if investors are increasingly demanding for better integration of sustainability into investment processes, also clients are demonstrating a mounting interest for responsible and sustainable investing (Blackrock Investment Institute, 2019). Thus, they are even more demanding for social and/or environmental benefits and tend to consider SRI as able to minimize risks, fulfill a fiduciary duty and improve returns (Global Sustainable Investment Alliance, 2018). This is possible implementing specific strategies that incorporate ESG criteria into investment decisions and that point to create sustainable and long-term returns and value (Stake, 2013; Eurosif, 2018). In this, sense, the analysis highlighted that even though full integration of ESG criteria in investment strategies can contribute to mitigate ESG risks and to capitalize the related opportunities, it tends to differ according to the allocation (market) of investment funds, according to corporate EGS policy and the selected SRI strategy. The achieved results demonstrated that even though the case companies open to disclose information about their ESG efforts, almost all of them seem to be far from the full integration of ESG criteria. This implies that these companies tend to focus their informative and communicative efforts on disclosing just the positive progress they made in some of the ESG issues.

Comparing the achieved results, just the third case company resulted quite near to full integration, while the others demonstrated less than a full commitment to ESG. This led to focus on the third company approach to SRI and in particular on its proactivity in communicating the efforts done in terms of ESG issues, which must be necessarily based on the close collaboration between SRI fund managers, SRI analyst and CRS managers. This is also what the literature is still calling for. Moreover, results demonstrate a quite opposite situation for the fifth case company, which demonstrated a limited disposition toward the communication of ESG different dimensions, which according to previous research tend to be a barrier to acceptance by investors and other stakeholders (Slack and Tsalavoutas, 2018). The fewer occurrences of the analyzed dimensions (keywords) have been found in the KIID that this company published for 2020. The remaining three companies (company 2, 3, and 4) demonstrated a quite similar level of disclosure, paying attention and communicating about similar dimensions of ESG issues. This paves the way to the progressive definition of a shared communication standard, which through the KIID, can support AMCs in reaching and informing their audience. 
TQM

33,7

This achieved result is in line with the mainstream research, which focuses on the different methods and strategies that managers adopt for ESG integration, ranging from active ownership and engagement to positive screening, "best-in-class selection" or even to the full integration (Cappucci, 2018). However, the aforementioned strategies are not self-exclusive but can be combined according to asset classes and/or products peculiarities (Ecceles et al., 2017). This led to address the first research question at the core of this analysis (RQ1: To what extent ESG criteria are integrated into SRI strategies:').

Results pointed out another interesting evidence, which is in line with the current call for more reliable and transparent information and communication about SRI and, at the same time, about corporate sustainability performance (Berthelot et al., 2012; Diouf and Boiral, 2017). The sample companies demonstrated a quite similar approach to SRI strategies, in which - even though with a different deepness - they mostly incorporate issues about society, governance, sustainable development and environment. This finding is in line with the extant literature, which underlined the trends among analysts and fund managers to incorporate ESG information into investment strategies to restore social legitimacy, governance in terms of corporate accountability and sustainable development (Talan and Sharma, 2019). This also led to expanding the opportunities included in traditional financial analysis (Revelli, 2017), because these information measures companies' nonfinancial performances. In this vein, Eccles and Kastrapeli maintained that "only full ESG integration has the potential to deliver on the goal of sustainable value creation for all investors." (2017, p. 21), which can decide to participate or not to this process accessing information about AMCs approach to ESG and their integration into investment strategies. That is the way SRI contribute to the sustainable development of the financial system at the first and then, of the whole society (Busch et al., 2016).

The finding presented above emerged from the way the case companies approached and developed their KIIDs, which were very similar both in their form and in their contents. Thus, all the analyzed documents presented a good level of communicative rigor; therefore, even though their development and publication remain voluntary, it seems that a new communication standard (both in terms of communication style and in approached themes) has been voluntary and informally created as well as implemented by the most of $\mathrm{AMCs}$, according to a bottom-up process. This finding partially fits with the extant literature, according to which the enduring difficulties related to the quality, reliability and credibility of SRI strategies communication have led AMCs to approach the related tools (e.g. KIIDs) as mere marketing tools (Boiral et al., 2019; Tseng et al., 2019). Consequently, they usually tend to use them for gaining or increasing corporate social legitimation, rather than as a source of reliable information for stakeholders (Deegan and Blomquist, 2006; Boiral et al., 2019). All these considerations led to address the second research question (RQ2: "Do KIIDs contain some possible ESG issues that can inspire AMC to further develop their SRI strategies?”).

\section{Implications and final remarks}

This study fits into the sustainable development research field, shedding light on how ESG criteria have been applied to asset management in terms of investment strategy and ESG communication. The analysis was built on a sample of AMCs and considered some of the KIIDs they published in 2020 for understanding if and to what extend ESG criteria have been integrated into investment strategies. Even though the achieved results demonstrated a growing awareness about the need for pushing finance toward sustainability, the effort dedicated to achieving this goal highly varies across industries and sectors as well as AMCs. To effectively contribute to the grand challenge of sustainable development, a clear and transparent communication about ESG conduct is essential to retain investors' and stakeholders' trust (Ho, 2013; Chen et al., 2018). Thus, to attract investors and to meet their 
need for information about the social and environmental externalities of their asset management practices, AMCs are gradually integrating the ESG criteria into their financial communication (i.e. KIID) through a voluntary and additional disclosure relying upon accuracy and transparency of the related concerns (Jebe, 2019). This implies that to invest in sustainable companies and to better manage the related decision-making process, institutional and individual investors need accurate financial and nonfinancial information, grasped through standardized tools. Due to the lack of these standardized and well-established tools, AMCs adopted a self-regulated approach to responding to the aforementioned need (Diouf and Boiral, 2017). So, what this study contributed to understanding is the need for a better and more standardized communication of the environmental and social impact of SRI, together with the establishment of better and shared ways to measure this impact, to further stimulate investors choice and, in so doing, to push finance toward sustainability. It follows that some implications can be outlined. This study contributed to better understand the potential of ESG integration and the related communication for the transition of investment behavior toward a more responsible and sustainable approach (micro-level), which can add long-lasting sustainability to the whole society (macro-level). Moreover, the policy implications of this study also suggest that financial markets need for a construct validity related to the integration of ESG criteria, pointing to institutionalize and aligning investors' expectations with investees' practices. This in turn might frame narrow boundaries for the transition toward a more sustainable finance, defining a clear pattern which enables investors to improve the efficiency of their ESG portfolios. Besides, institutional investors might benefit from ESG integration in diversifying their investment opportunities, aiming to mitigate the possible risk exposure to market volatility during bearish market phases. This contributed to make them even more aware about the importance and the advantages coming from the implementation of specific SRI strategies, such as (positive or negative) screening, exclusion and, even, ESG integration (ENG, 2016).

In terms of SRI strategies, AMCs, managers and consultants in developing and implementing them could be much more focused on the way they approach ESG integration and the related communication. Even though a concrete evaluation of this integration within the broader assessment of overall investment skills remains difficult, asset managers and consultants could be much more aware of the importance and the influence that the inclusion of the related criteria can have on their investment decision-making (Cappucci, 2018). Thus, recently national and international laws and regulations are trying to encourage their attitude toward integration both in developed and emerging markets, increasing information about integration itself and its respect of fiduciary duties (Global Sustainable Investment Alliance, 2018). Even though this study attempted to contribute to the extant literature on ESG integration into SRI strategies, its inherently explorative and qualitative nature somewhat limits it; thus, further research based on quantitative methods and a wider sample of analysis will be conducted.

\section{Notes}

1. According to the Global Sustainable Investment Alliance (GSI Alliance, 2020), in 2018 SRI assets globally covered $34 \%$ of total assets under management. The percentage raised to $52.6 \%$ of global sustainable investment assets in Europe (European Sustainable Investment Forum, Eurosif, 2016).

2. Novethic is a French media and a research center, considered as one of the most influential media in France and Europe in terms of all corporate social responsibility (CSR) and SRI issues.

3. SASB (Sustainability Accounting Standards Board) is a US nonprofit organization established in 2011, which mission is to develop measurement standards for reporting on material environmental, social and governance (ESG) issues (or "non-financial information") relevant and reliable as accounting standards for financial information.

4. United Nations Principles for Responsible Investment. 
TQM

33,7

\section{References}

Alliance, G.S.I. (2018), Global Sustainable Investment Review, GSIA Report, April.

Alliance, G.S.I. (2020), Global Sustainable Investment Review, available at: http://www.gsi-alliance.org/ wp-content/uploads/2017/03/GSIR_Review2018 (accessed May 2020).

Arefeen, S. and Shimada, K. (2020), "Performance and Resilience of socially responsible investing (SRI) and conventional funds during different shocks in 2016: evidence from Japan", Sustainability, Vol. 12 No. 2, pp. 540-552.

Ashrafi, M., Adams, M., Walker, T.R. and Magnan, G. (2018), "How corporate social responsibility can be integrated into corporate sustainability: a theoretical review of their relationships", The International Journal of Sustainable Development and World Ecology, Vol. 25 No. 8, pp. 672-682.

Belghitar, Y., Clark, E. and Deshmukh, N. (2014), "Does it pay to be ethical? Evidence from the FTSE4Good", Journal of Banking and Finance, Vol. 47, pp. 54-62.

Berthelot, S., Coulmont, M. and Serret, V. (2012), "Do investors value sustainability reports? A Canadian study", Corporate Social Responsibility and Environmental Management, Vol. 19 No. 6, pp. 355-363.

Biong, H. and Silkoset, R. (2017), "Buying CSR with employees' pensions? The effect of social responsible investments on Norwegian SMEs' choice of pension fund management", International Journal of Bank Marketing, Vol. 35 No. 1, pp. 56-74.

Blackrock Investment Institute (2019), "Sustainability: The future of investing", available at: https:// www.blackrock.com/us/individual/literature/whitepaper/bii-sustainability-future-investing-jan2019.pdf (accessed May 2020).

Boiral, O., Heras-Saizarbitoria, I. and Brotherton, M.C. (2019), “Assessing and improving the quality of sustainability reports: the auditors' perspective”, Journal of Business Ethics, Vol. 155 No. 3, pp. 703-721.

Bouma, J.J., Jeucken, M. and Klinkers, L. (Eds) (2017), Sustainable Banking: The Greening of Finance, Routledge, London.

Busch, T., Bauer, R. and Orlitzky, M. (2016), "Sustainable development and financial markets: old paths and new avenues", Business and Society, Vol. 55 No. 3, pp. 303-329.

Capelle-Blancard, G. and Petit, A. (2019), "Every little helps? ESG news and stock market reaction", Journal of Business Ethics, Vol. 157 No. 2, pp. 543-565.

Cappucci, M. (2018), "The ESG integration paradox", Journal of Applied Corporate Finance, Vol. 30 No. 2, pp. 22-28.

Ceravolo, M.G., Cerroni, R., Farina, V., Fattobene, L., Leonelli, L., Mercuri, N.B. and Raggetti, G. (2019), "Attention allocation to financial information: the role of color and impulsivity personality trait", Frontiers in Neuroscience, Vol. 13, pp. 818-831.

Chatzitheodorou, K., Skouloudis, A., Evangelinos, K. and Nikolaou, I. (2019), "Exploring socially responsible investment perspectives: a literature mapping and an investor classification", Sustainable Product and Consumption, Vol. 5, pp. 56-78.

Chen, X. and Scholtens, B. (2018), "The urge to act: a comparison of active and passive socially responsible investment funds in the United States", Corporate Social Responsibility and Environmental Management, Vol. 25 No. 6, pp. 1154-1173.

Conti, T. (2017), "Cultural and ethical obstacles on the road to sustainable development in the globalization era", The TQM Journal, Vol. 29 No. 6, pp. 920-935.

Crifo, P., Durand, R. and Gond, J.P. (2019), "Encouraging investors to enable corporate sustainability transitions: the case of responsible investment in France", Organization and Environment, Vol. 32 No. 2, pp. 125-144.

Cubas-Díaz, M. and Martinez Sedano, M.A. (2018), "Measures for sustainable investment decisions and business strategy-a triple bottom line approach", Business Strategy and the Environment, Vol. 27 No. 1, pp. 16-38. 
Cumming, D. and Johan, S. (2007), "Socially responsible institutional investment in private equity", Journal of Business Ethics, Vol. 75 No. 4, pp. 395-416.

Deegan, C. and Blomquist, C. (2006), "Stakeholder influence on corporate reporting: an exploration of the interaction between WWF-Australia and the Australian minerals industry", Accounting, Organizations and Society, Vol. 31 Nos 4-5, pp. 343-372.

Derwall, J., Koedijk, K. and Ter Horst, J. (2011), "A tale of values-driven and profit-seeking social investors”, Journal of Banking and Finance, Vol. 35 No. 8, pp. 2137-2147.

Dillenburg, S., Greene, T. and Erekson, O.H. (2003), "Approaching socially responsible investment with a comprehensive ratings scheme: total social impact", Journal of Business Ethics, Vol. 43 No. 3, pp. 167-177.

Diouf, D. and Boiral, O. (2017), "The quality of sustainability reports and impression management", Accounting, Auditing and Accountability Journal, Vol. 30 No. 3, pp. 112-130.

Eccles, R.G. and Kastrapeli, M.D. (2017), “The investing enlightenment”, State Street, pp. 1-40.

Eccles, R.G., Kastrapeli, M.D. and Potter, S.J. (2017), "How to integrate ESG into investment decisionmaking: results of a global survey of institutional investors", Journal of Applied Corporate Finance, Vol. 29 No. 4, pp. 125-133.

Elkington, J. (1997), "The triple bottom line”, Environmental Management: Readings and cases, Vol. 2.

ENG (2016), "Marktbericht Nachhaltige Geldanlagen”, available at: http://www.inrate.com/ getattachment/Site/NewsEvents/News/Sustainable-Investments-increased-over-30-in-2015/ FNG_Marktbericht2016_online.pdf.aspx (accessed May 2020).

Escrig-Olmedo, E., Muñoz-Torres, M.J. and Fernández-Izquierdo, M.Á. (2013), "Sustainable development and the financial system: Society's perceptions about socially responsible investing", Business Strategy and the Environment, Vol. 22 No. 6, pp. 410-428.

Escrig-Olmedo, E., Fernández-Izquierdo, M.Á., Ferrero-Ferrero, I., Rivera-Lirio, J.M. and Muñoz-Torres, M.J. (2019), "Rating the raters: evaluating how ESG rating agencies integrate sustainability principles", Sustainability, Vol. 11 No. 3, pp. 915-929.

Eurosif (2016), "European SRI study 2016", available at: http://www.eurosif.org/research (accessed May 2020).

Eurosif (2018), "European SRI study 2018”, available at: http://www.eurosif.org/ (accessed May 2020).

Formánková, S., Trenz, O., Faldík, O., Kolomazník, J. and Sládková, J. (2019), "Millennials' awareness and approach to social responsibility and investment — case study of the Czech Republic", Sustainability, Vol. 11 No. 2, pp. 504-519.

Freide, G., Busch, T. and Bassen, A. (2015), "ESG and financial performance: aggregated evidence from more than 2000 empirical studies", Journal of Sustainable Finance and Investment, Vol. 5 No. 4, pp. 210-233.

Giljum, S., Hak, T., Hinterberger, F. and Kovanda, J. (2005), "Environmental governance in the European Union: strategies and instruments for absolute decoupling", International Journal of Sustainable Development, Vol. 8 Nos 1-2, pp. 31-46.

Global Economic Dynamics (2019), "The pros and cons of globalization", available at: https:// gedproject.de/allgemein-en/the-pros-and-cons-of-globalization/ (accessed June 2020).

Gutsche, G. and Zwergel, B. (2020), "Investment barriers and labeling schemes for socially responsible investments", Schmalenbach Business Review, Vol. 3, pp. 1-47.

Ho, M. (2013), "The social construction perspective on ESG issues in SRI indices", Journal of Sustainable Finance and Investment, Vol. 3 No. 4, pp. 360-373.

Houghton, C., Casey, D., Shaw, D. and Murphy, K. (2013), "Rigour in qualitative case-study research", Nurse Researcher, Vol. 20 No. 4, pp. 20-33.

Jebe, R. (2019), "The convergence of financial and ESG materiality: taking sustainability mainstream", American Business Law Journal, Vol. 56 No. 3, pp. 645-702. 
TQM 33,7

Joliet, R. and Titova, Y. (2018), "Equity SRI funds vacillate between ethics and money: an analysis of the funds' stock holding decisions", Journal of Banking and Finance, Vol. 97, pp. 70-86.

Kohlbacher, F. (2006), "The use of qualitative content analysis in case study research", Forum Qualitative Sozialforschung/Forum: Qualitative Social Research, Vol. 7 No. 1, pp. 1-30.

Kotsantonis, S., Pinney, C. and Serafeim, G. (2016), "ESG integration in investment management: myths and realities", Journal of Applied Corporate Finance, Vol. 28 No. 2, pp. 10-16.

Krippendorff, K. (2004), "Reliability in content analysis: some common misconceptions and recommendations", Human Communication Research, Vol. 30 No. 3, pp. 411-433.

Landi, G. and Sciarelli, M. (2019), "Towards a more ethical market: the impact of ESG rating on corporate financial performance”, Social Responsibility Journal, Vol. 2 No. 1, pp. 30-45.

Lo, K.Y. and Kwan, C.L. (2017), "The effect of environmental, social, governance and sustainability initiatives on stock value? Examining market response to initiatives undertaken by listed companies", Corporate Social Responsibility and Environmental Management, Vol. 24 No. 6, pp. 606-619.

Lokuwaduge, C.S.D.S. and Heenetigala, K. (2017), "Integrating environmental, social and governance (ESG) disclosure for a sustainable development: an Australian study", Business Strategy and the Environment, Vol. 26 No. 4, pp. 438-450.

Mason, E.J. and Bramble, W.J. (1989), Understanding and Conducting Research: Applications in Education and the Behavioral Sciences, McGraw-Hill Companies, New York.

Matallín-Sáez, J.C., Soler-Domínguez, A., de Mingo-López, D.V. and Tortosa-Ausina, E. (2019), "Does socially responsible mutual fund performance vary over the business cycle? New insights on the effect of idiosyncratic SR features", Business Ethics: A European Review, Vol. 28 No. 1, pp. 71-98.

Matharu, J.S. (2019), "Socially responsible investing”, The Management Accountant Journal, Vol. 54 No. 11, pp. 92-94.

Michelson, G., Wailes, N., Van Der Laan, S. and Frost, G. (2004), "Ethical investment processes and outcomes", Journal of Business Ethics, Vol. 1, pp. 35-76.

Miralles-Quiros, M.D.M., Miralles-Quiros, J.L. and Arraiano, I.G. (2017), "Are firms that contribute to sustainable development valued by investors?", Corporate Social Responsibility and Environmental Management, Vol. 24 No. 1, pp. 71-84.

Newman, D.A. (2003), "Longitudinal modeling with randomly and systematically missing data: a simulation of ad hoc, maximum likelihood, and multiple imputation techniques", Organizational Research Methods, Vol. 6 No. 3, pp. 328-362.

Nilsson, J., Nordvall, A.C. and Isberg, S. (2016), "The information search process of socially responsible investors", Financial Literacy and the Limits of Financial Decision-Making, Palgrave Macmillan, Cham, pp. 57-76.

Novethic (2010), “Achieving investment objectives through ESG integration”, available at: http://www. novethic.com/fileadmin/userupload/txausynovethicetudes/pdfcomplets/ESGIntegration2010. pdf (accessed June 2020).

Oehler, A., Horn, M. and Wendt, S. (2018), "Why self-commitment is not enough: on a regulated minimum standard for ecologically and socially responsible financial products and services", Designing a Sustainable Financial System, Palgrave Macmillan, Cham, pp. 405-421.

Palma-Ruiz, J.M., Castillo-Apraiz, J. and Gómez Martínez, R. (2020), "Socially responsible investing as a competitive strategy for trading companies in times of upheaval amid COVID-19: evidence from Spain”, International Journal of Financial Studies, Vol. 8 No. 3, p. 41.

Parida, S. and Wang, Z. (2018), "Financial crisis and corporate social responsible mutual fund flows", International Journal of Financial Studies, Vol. 6 No. 1, p. 8.

Principles for Responsible Investment (PRI) (2017), The SDG Investment Case, New York, NY.

Przychodzen, J., Gómez-Bezares, F., Przychodzen, W. and Larreina, M. (2016), "ESG Issues among fund managers-factors and motives", Sustainability, Vol. 8 No. 10, pp. 1078-1085. 
Renneboog, L., Ter Horst, J. and Zhang, C. (2008), "Socially responsible investments: institutional aspects, performance, and investor behavior", Journal of Banking and Finance, Vol. 32 No. 9, pp. 1723-1742.

Revelli, C. (2016), "Re-embedding financial stakes within ethical and social values in socially responsible investing (SRI)", Research in International Business and Finance, Vol. 38, pp. 1-5.

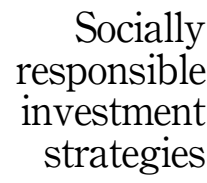

Revelli, C. (2017), "Socially responsible investing (SRI): from mainstream to margin?", Research in International Business and Finance, Vol. 39, pp. 711-717.

Ryszawska, B. (2016), "Sustainability transition needs sustainable finance", Copernican Journal of Finance and Accounting, Vol. 5 No. 1, pp. 185-194.

Scholtens, B. (2006), "Finance as a driver of corporate social responsibility", Journal of Business Ethics, Vol. 68 No. 1, pp. 19-33.

Slack, R. and Tsalavoutas, I. (2018), "Integrated reporting decision usefulness: mainstream equity market views", Accounting Forum, Vol. 42 No. 2, pp. 184-198, No longer published by Elsevier.

Stake, R.E. (2013), Multiple Case Study Analysis, Guilford press, London.

Steffen, W., Broadgate, W., Deutsch, L., Gaffney, O. and Ludwig, C. (2015), "The trajectory of the Anthropocene: the great acceleration", The Anthropocene Review, Vol. 2 No. 1, pp. 81-98.

Steffen, W., Rockström, J., Richardson, K., Lenton, T.M., Folke, C., Liverman, D., Summerhayes, C.P., Barnosky, A.D., Cornell, S.E., Crucifix, M. and Donges, J.F. (2018), "Trajectories of the earth system in the anthropocene", Proceedings of the National Academy of Sciences, Vol. 115 No. 33, pp. 8252-8259.

Sustainability Accounting Standard Board (2011), "Sustainability accounting standard board, sasb's approach to materiality for the purpose of standardsdevelopment", available at: http://ibrary. sasb.org/wp-content/uploads/2017/01/ApproachMateriality-Staff-Bulletin-01192017.pdf? hsCtaTracking $=9280788 \mathrm{c}-\mathrm{d} 775-4 \mathrm{~b} 34-8 \mathrm{bc} 8-5447 \mathrm{a} 06 \mathrm{a} 6 \mathrm{~d} 38 \%$ 7C2e22652a-5486-4854-b68f73fea01a241 (accessed June 2020).

Syed, A.M. (2017), "Environment, social, and governance (ESG) criteria and preference of managers", Cogent Business and Management, Vol. 4 No. 1, pp. 134-148.

Talan, G. and Sharma, G.D. (2019), "Doing well by doing good: a systematic review and research agenda for sustainable investment”, Sustainability, Vol. 11 No. 2, p. 353.

Tsai, W.H., Chou, W.C. and Hsu, W. (2009), "The sustainability balanced scorecard as a framework for selecting socially responsible investment: an effective MCDM model", Journal of the Operational Research Society, Vol. 60 No. 10, pp. 1396-1410.

Tseng, M.L., Tan, P.A., Jeng, S.Y., Lin, C.W.R., Negash, Y.T. and Darsono, S.N.A.C. (2019), "Sustainable investment: interrelated among corporate governance, economic performance and market risks using investor preference approach”, Sustainability, Vol. 11 No. 7, pp. 182-198.

UNPRI (United Nations Principles for Responsible Investment) (2015), available at: http://www.unpri. org (accessed June 2020).

Van Duuren, E., Plantinga, A. and Scholtens, B. (2016), "ESG integration and the investment management process: fundamental investing reinvented", Journal of Business Ethics, Vol. 138 No. 3, pp. 525-533.

Vanwalleghem, D. (2017), “The real effects of sustainable and responsible investing?", Economics Letters, Vol. 156, pp. 10-14.

Widyawati, L. (2019), "A systematic literature review of socially responsible investment and environmental social governance metrics", Business Strategy and the Environment, Vol. 29 No. 2, pp. 619-637.

World Commission on Environment and Development, and Brundtland, G. H (1987), Presentation of the Report of the World Commission on Environment and Development to the Commission of the European Communities, the EC and EFTA Countries, 5 May 1987, World Commission on Environment and Development, Brussels. 
TQM 33,7

56

World Economic Forum (2011), The Global Economic Burden of Noncommunicable Diseases, Geneva. Yin, R. (2003), Case Study Research: Design and Methods, Sage Publishing, Beverly Hills.

\section{Further reading}

Cerin, P. and Scholtens, B. (2011), "Linking responsible investments to societal influence: motives, assessments and risks", Sustainable Development, Vol. 19 No. 2, pp. 71-76.

Keitsch, M.M. (2010), "Sustainability and science-challenges for theory and practice", Sustainable Development, Vol. 18 No. 5, pp. 241-244.

\section{Appendix}

\begin{tabular}{|c|c|c|}
\hline Categories & $\begin{array}{l}\text { Occurrences' per } \\
\text { category }\end{array}$ & Keywords \\
\hline $\begin{array}{l}\text { Society and } \\
\text { governance }\end{array}$ & 5.530 & $\begin{array}{l}\text { Accounting, award*, bank*, board*, business, competit*, } \\
\text { corporat*, CSR, customer*, disclosure, engagement, } \\
\text { entrepreneur*, equit*, ESG, ethics, fund*, govern*, institution*, } \\
\text { integration, law*, manag*, optimization, pension*, portfolio, } \\
\text { positive, price, product*, progress, quality, regulation*, renew*, } \\
\text { report*, responsib*, result*, service*, social, SRI, stakeholder*, } \\
\text { stock*, target }\end{array}$ \\
\hline Climate change & 4.021 & $\begin{array}{l}\text { Association*, biodegradable*, biodiversity*, carbon, change*, } \\
\text { climate, collect*, consumption, efficien*, emission*, energy*, } \\
\text { gas, generation, global, green*, GRI, fuel*, material*, natur*, oil*, } \\
\text { pollution, source*, train*, wast*, water, wind }\end{array}$ \\
\hline Healthcare & 4.550 & $\begin{array}{l}\text { Age, care*, children*, clinic*, condition*, chronic, disease*, } \\
\text { doctor*, effective*, elder, health*, healthcare, hospita*', } \\
\text { inequality, information, medical, medicine, surgery, physician*, } \\
\text { use, wellness, wellbeing* }\end{array}$ \\
\hline Global compact & 6.124 & $\begin{array}{l}\text { Access, anticorruption, commit*, communication, complian* } \\
\text { compact, compensation*, democracy, diversit*, educat*, } \\
\text { employ*, famil*, finance*, gender*, group*, happ*, hunger*, } \\
\text { invest*, knowledge, learn*, lobby*, market*, minority, } \\
\text { monitoring, non-discriminat*, occupation, performance*, polic*, } \\
\text { poor*, poverty, priorit*, problem*, religion*, retirement, right*, } \\
\text { risk*, strateg*, transport*, skill*, support, values, welfare, work }\end{array}$ \\
\hline $\begin{array}{l}\text { Sustainable } \\
\text { development }\end{array}$ & 8.902 & $\begin{array}{l}\text { Communit*, culture, econom*, engagement, environment*, } \\
\text { firm*, freedom, future, gain*, goal*, incentive*, indicator*, } \\
\text { involv*, long-term, objective*, opportun*, orientation, people, } \\
\text { politic*, pressure, principle*, positive, public, rich*, safety, } \\
\text { security, society, standard*, sustainab*, value*, wellbeing* }\end{array}$ \\
\hline
\end{tabular}

Table A1.

Items and indicators rising from the content analysis

Source(s): authors' elaboration

Accounting, award*, bank*, board*, business, competit*, corporat*, CSR, customer*, disclosure, engagement, integration, law*, manag*, optimization, pension*, portfolio, positive, price, product*, progress, quality, regulation*, renew*, report*, responsib*, result*, service*, social, SRI, stakeholder*, stock*, target climate, collect* consumption, efficien* emission* energy* gas, generation, global, green*, GRI, fuel*, material*, natur*, oil*, pollution, source*, train*, wast*, water, wind doctor*, effective*, elder, health*, healthcare, hospital*, inequality, information, medical, medicine, surgery, physician*, use, wellness, wellbeing* compact, compensation*, democracy, diversit*, educat*, employ*, famil*, finance*, gender*, group*, happ*, hunger*, invest*, knowledge, learn*, lobby*, market*, minority, monitoring, non-discriminat*, occupation, performance*, polic*, poor*, poverty, priorit*, problem*, religion*, retirement, right*, Communit*, culture, econom*, engagement, environment*, firm*, freedom, future, gain*, goal*, incentive*, indicator*, involv*, long-term, objective*, opportun*, orientation, people, politic*, pressure, principle*, positive, public, rich*, safety, security, society, standard*, sustainab*, value*, wellbeing*

\section{Corresponding author}

Silvia Cosimato can be contacted at: silvia.cosimato@unina.it

For instructions on how to order reprints of this article, please visit our website:

www.emeraldgrouppublishing.com/licensing/reprints.htm

Or contact us for further details: permissions@emeraldinsight.com 